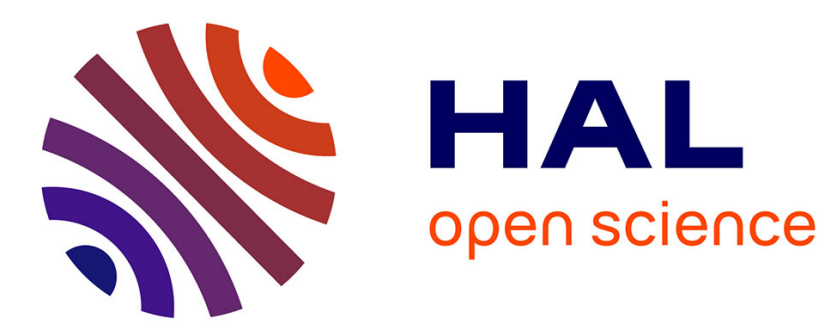

\title{
Recent progress in the study of fine-scale physical-biological coupling in the Mediterranean Sea.
} Roxane Tzortzis, Andrea M. Doglioli, Stéphanie Barrillon, A. A Petrenko, Francesco d'Ovidio, Lloyd Izard, Melilotus Thyssen, Nagib Bhairy, Ananda Pascual, Bàrbara Barceló-Llull, et al.

\section{To cite this version:}

Roxane Tzortzis, Andrea M. Doglioli, Stéphanie Barrillon, A. A Petrenko, Francesco d'Ovidio, et al.. Recent progress in the study of fine-scale physical-biological coupling in the Mediterranean Sea.. EGU General Assembly 2021, Apr 2021, Vienne, Austria. 10.5194/egusphere-egu21-7133 . hal-03375405

\author{
HAL Id: hal-03375405 \\ https://hal.science/hal-03375405
}

Submitted on 12 Nov 2021

HAL is a multi-disciplinary open access archive for the deposit and dissemination of scientific research documents, whether they are published or not. The documents may come from teaching and research institutions in France or abroad, or from public or private research centers.
L'archive ouverte pluridisciplinaire HAL, est destinée au dépôt et à la diffusion de documents scientifiques de niveau recherche, publiés ou non, émanant des établissements d'enseignement et de recherche français ou étrangers, des laboratoires publics ou privés.

\section{(c)(1)}

Distributed under a Creative Commons Attribution| 4.0 International License 


\section{Recent progress in the study of fine-scale physical-biological coupling in the Mediterranean Sea}

$\left(\begin{array}{l}\text { Institut Pythéas } \\ \text { observatoire des Sciences de l'Univers } \\ \text { Aix: Marseille Université }\end{array}\right.$

R. Tzortzis, A.M. Doglioli, S. Barrillon, A.A. Petrenko, F. d'Ovidio, L. Izard, M. Thyssen, N. Bhairy, J.-L. Fuda, A. Pascual,

B. Barceló-Llull, F. Cyr, M. Tedetti, P. Garreau, F. Dumas, L. Bordois, C. Comby, L. Rousselet, G. Gregori.

\section{Context}

\section{Adaptative and Lagrangian strategy}

Fine scales : Structures (fronts, eddies) with horizontal scales in order of $\mathbf{1 0 ~} \mathbf{~ k m}$ to $\mathbf{1 0 0} \mathbf{~ k m}$ with a short lifetime (days/weeks).

$\rightarrow$ Predominantly studied with numerical simulations and satellite observations.

$\rightarrow$ Models have highlight the impact of fine scales on biological processes in particular on the distribution of phytoplankton. $\rightarrow$ PROTEVSMED-SWOT 2018 campaign.

$\rightarrow$ Identification of $\mathbf{2}$ types of water with different [Chl] with satellite observation.

Necessity of in situ $\rightarrow$ Route of the ship accross these 2 types of water.

Necessity of in situ $\rightarrow$ Sampling at high spatial and temporal resolution.

\section{Hydrodynamical}

$\rightarrow$ Identification of a front with the horizontal currents. $\rightarrow$ Estimation of vertical velocities $\mathbf{w}$ with equation omega (Hoskin et al., 1978).
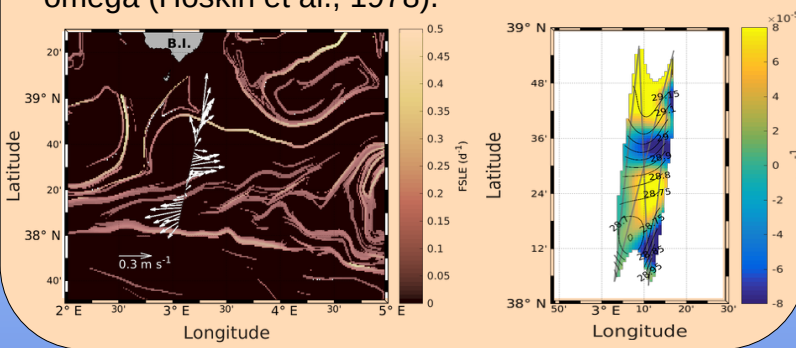

\section{Hydrological}

$\rightarrow$ Identification of 2 types of Atlantic Water (AW) at different stages of mixing in surface, separated in the frontal area.
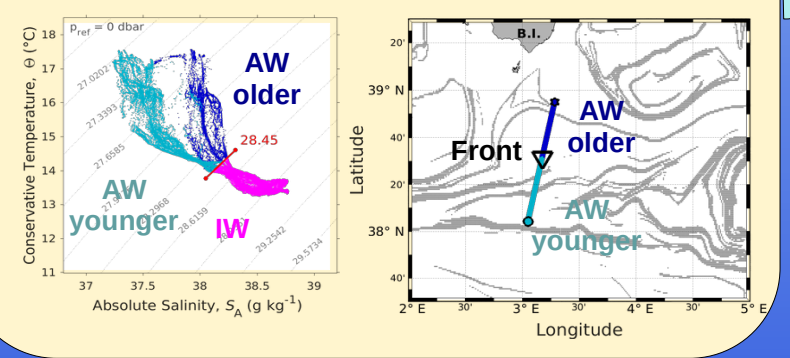

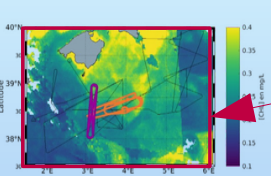

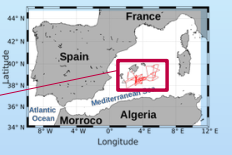

\section{Results and conclusion}

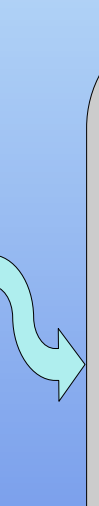

\section{.}

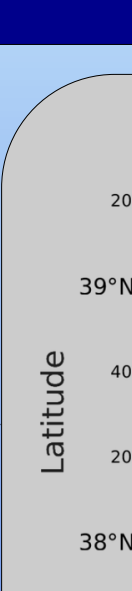
https://doi.org/10.5194/bg-2021-38, in review, 2021.

\section{Physical-biological coupling}

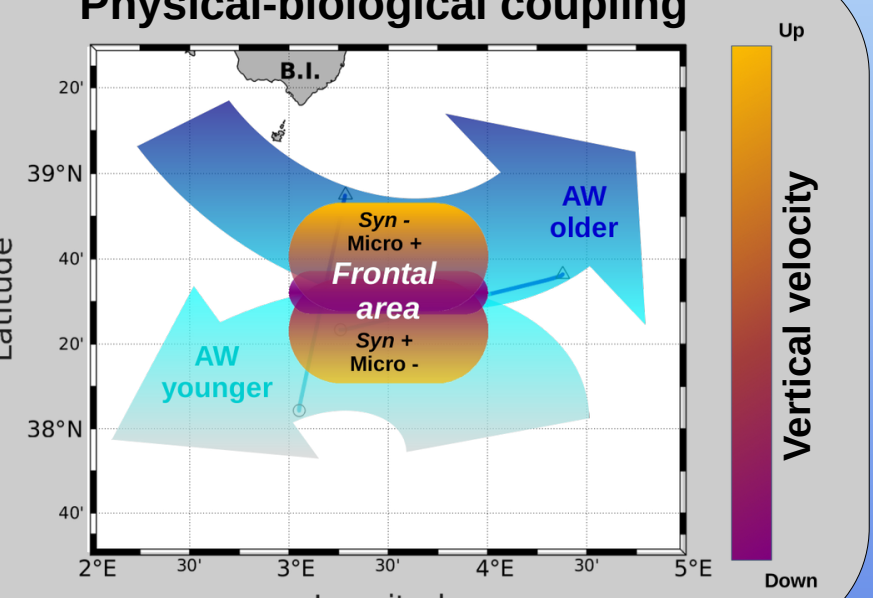

Longitude

\section{Conclusion}

$\rightarrow$ Impact of the front on the distribution of phytoplankton. $\rightarrow$ Barrier role of the front as described by models.

\section{Biological}

Abundances of phytoplankton separated by the front.

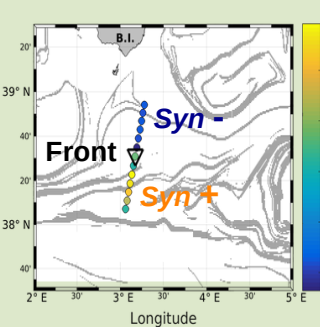

Synechococcus

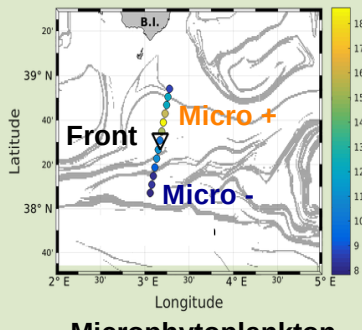

Microphytoplankton zortzis, R., et al.,; Impact of moderate energetic fine-scale dynamics on the phytoplankton community structure in the western Mediterranean Sea, Biogeosciences Discuss. [preprint]

\section{Perspectives}

$\rightarrow$ A new satellite to better observe fine scale structures in the global ocean : SWOT 2023.

$\rightarrow$ Initiative 'Adopt a SWOT crossover' :

community to coordinate future cruises in the crossover's areas, before and during the SWOT mission.
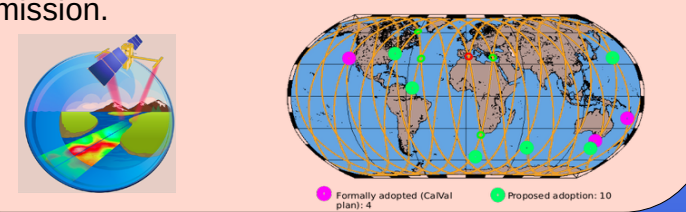

Encourages the international scientific 